6-1994

\title{
Evaluating the Success of Urban Success Stories
}

\author{
Harold L. Wohlman \\ Wayne State University \\ Coit Cook Ford III \\ Wayne State University \\ Edward W. Hill \\ Cleveland State University, e.hill@csuohio.edu
}

Follow this and additional works at: https://engagedscholarship.csuohio.edu/urban_facpub

Part of the Urban Studies and Planning Commons

How does access to this work benefit you? Let us know!

Publisher's Statement

(c) 1994 SAGE Publications

\section{Original Citation}

Wolman, H. L., Ford, C. C., \& Hill, E. (1994). Evaluating the Success of Urban Success Stories. Urban Studies, 31, 6, 835-850.

\section{Repository Citation}

Wohlman, Harold L.; Ford, Coit Cook III; and Hill, Edward W., "Evaluating the Success of Urban Success Stories" (1994). All Maxine Goodman Levin School of Urban Affairs Publications. 012375.

https://engagedscholarship.csuohio.edu/urban_facpub/75

This Article is brought to you for free and open access by the Maxine Goodman Levin School of Urban Affairs at EngagedScholarship@CSU. It has been accepted for inclusion in All Maxine Goodman Levin School of Urban Affairs Publications by an authorized administrator of EngagedScholarship@CSU. For more information, please contact library.es@csuohio.edu. 


\title{
EVALUATING THE SUCCESS OF URBAN SUCCESS STORIES
}

\author{
Harold L. Wolman, Wayne State University \\ Coit Cook Ford III, Wayne State University \\ Edward Hill, Cleveland State University
}

This article was originally published in:

Wolman, Harold L., et al. (1993). Evaluating the Success of Urban Success Stories. Urban Studies, 31(6), 835-850.

Post-print standardized by MSL Academic Endeavors, the imprint of the Michael Schwartz Library at Cleveland State University, 2012

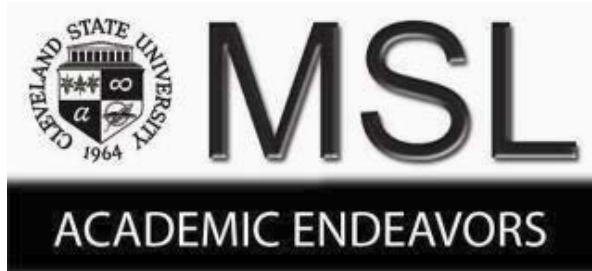




\title{
Evaluating the Success of Urban Success Stories
}

\author{
Harold L. Wolman, Coit Cook Ford III and Edward Hill
}

\begin{abstract}
Summary. Arresting and reversing the condition of urban distress in America's cities represents one of the most challenging and perplexing problems confronting policy-makers. Indeed, urban distress in American cities has proved to be a stubborn and largely intractable phenomenon during the past two decades. Nevertheless, a number of cities that were experiencing distress at the beginning of the 1980s are now being acclaimed as 'urban success stories' or 'revitalised' cities. We evaluate the performance, between 1980 and 1990, of these supposedly 'revitalised' cities on objective indicators of the economic well-being of their residents and compare their performance to that other cities that were equally distressed in 1980 . We conclude that with the exception of Atlanta, Baltimore and Boston, the purportedly 'revitalised' cities performed no better with respect to change in the economic well-being of their residents than did other cities that were equally distressed in 1980 -and in many cases performed worse.
\end{abstract}

The condition of America's distressed urban areas represents one of the most serious and vexing problems facing the nation. Urban economic distress has been both persistent and highly resistant to policy solutions (see Bradbury et al., 1982). Yet, in the face of these problems, it is widely acknowledged that there have been examples of urban successes. Both popular and academic journals have heralded the revitalisation of cities such as Baltimore, Pittsburgh and, more recently, Cleveland. ${ }^{1}$ Such success stories have naturally attracted the attention and interest of public officials and community leaders in distressed cities that are desperately seeking solutions to their own problems. Indeed, delegations from distressed cities are frequent visitors to these 'successful' cities, hoping to learn from them and to emulate their success. Unfortunately, these visitors-and others who herald these 'urban success stories'are frequently quite unclear about the nature of these successes and the benefits they produce.

There are obviously many different ways of defining and measuring 'success'. Success may be viewed in terms of improvement in a variety of economic, social and physical conditions such as increased business investment, physical redevelopment, reduction in crime and infant mortality rates, increases in educational achievement, etc. In this paper, our concern is with improvement in the economic well-being of area residents, a concern

Harold L. Wolman and Coit Cook Ford III are in the College of Urban, Labor and Metropolitan Affairs, and the Department of Political Science, Wayne State University, Detroit, MI 48202, USA; and Edward Hill is in the Department of Urban Studies, College of Urban Affairs, Cleveland State University, Cleveland, OH 44115, USA. 
widely held to be of substantial importance. Our objective is to determine whether cities that are perceived to have undergone economic revitalisation have, at the same time, experienced improvement in the economic well-being of their residents. We pursue this objective by comparing changes in the economic well-being of residents in cities perceived to have undergone successful urban revitalisation to changes in the economic well-being of residents in cities that were similar to them prior to their supposed revitalisation. This will permit us to assess the extent to which 'urban success stories' are myth or reality, at least with respect to the economic well-being of their residents.

As Ladd and Yinger (1989) observe, urban revitalisation can benefit cities by improving

(1) their economic base (increasing employment and output in the city);

(2) their fiscal condition; or

(3) the well-being of their residents.

Well-being is a multi-faceted construct that includes economic, social and psychological components (see Wolman and Goldsmith, 1992, for a discussion of the concept of residential well-being). In this article, our concern is the extent to which the perceived 'urban success stories' have actually improved the economic well-being of their residents relative to that of residents of other cities that were similar to them, prior to their supposed revitalisation, in degree of distress. We do not address the relationship between perceived success and other objective success measures such as those previously discussed, although, we believe such relationships worthy of exploration, and invite others to apply our methodology to that end. Instead, we are concerned with whether public perceptions of success are related to reality, at least with respect to improvements in the economic well-being of city residents. Furthermore, we take these perceptions as given-i.e. we are not concerned with the causes of these perceptions or why they arise, but with whether these perceptions of success accord with reality. Such public per- ceptions, whatever their origins, are important, for they condition and influence the actions of policy-makers and community decision-makers, often in quite profound ways.

The question of whether urban revitalisation has actually benefited city residents has been widely discussed and debated in the literature (see, for example, the exchange between Levine (1987a, 1987b) and Berkowitz (1987), the various contributors in Squires (1989), Fainstein et al. (1986), Clavel (1986), Riposa and Andranovich (1988), Barnekov et al. (1989) and Brownhill (1990). However, it has not been the subject of systematic empirical research across a range of cities.

In order to pursue our objective we make use of a form of natural experiment. First, we identify cities that were distressed in 1980 , but have (purportedly) successfully revitalised since that time. We then compare the extent to which the economic well-being of the residents of these perceived 'successful' cities has improved from 1980 to 1990 , with that of the residents of cities which were similarly distressed in 1980 but are not perceived to have undergone successful revitalisation. We call the latter the perceived 'unsuccessful cities'. Finally, we identify those distressed cities in 1980 that, in fact, experienced the greatest increase in resident economic well-being during the past decade.

\section{Methodology}

The first step was to identify the 'urban success stories'-that is, cities that were distressed in 1980, but are widely believed to have successfully revitalised over the course of the past decade. Rather than relying on impressions from the media, we decided to consult expert opinion in a systematic manner. Specifically, we asked a set of highly informed observers to identify those cities that had been distressed in 1980 , but had undergone successful revitalisation by the end of the decade.

We began by identifying a set of cities that were distressed according to objective criteria in 1980. The first step involved devel- 
oping an index of urban distress. There is a substantial literature on what constitutes urban distress. Bradbury et al. (1982) distinguish between descriptive decline, which they measure through changes in population and employment, and functional distress, which they measure through changes in variables such as the unemployment rate, per capita income, the incidence of poverty and the rate of violent crime. Franklin James (1990) develops a 'city distress index' that combines resident needs, as measured by city poverty rate, unemployment rate and per capita income growth, and population change. Other measures abound (see, for example, Nathan and Adams (1976), Cuciti (1978) and Fossett and Nathan (1981). For reviews of this literature, see James (1990) and Sternlieb (1980).

Our urban distress index combines both descriptive and functional indicators and is quite similar to that of James (1990). We utilised five indicators:

(1) the 1980 unemployment rate;

(2) the 1980 poverty rate (persons);

(3) 1980 median household income

(4) percentage change between 1970 and 1980 in per capita income; and

(5) percentage change between 1970 and 1980 in population

A distribution of standard scores was created for each of the individual indicators. The indicators were standardised by converting them to $n$ scores. $^{2}$ The standardised scores for each city were then summed across all five indicators (thus weighting each of the indicators equally) to create a cumulative index of urban health (see Appendix) ${ }^{3}$ The bottom third of the cities in this distribution were designated as 'distressed' $(n=50)$.

We then solicited the opinions of a set of experts, sending them a survey letter that included the list of the 50 most distressed cities in 1980, and asking them to select up to 10 that had experienced the strongest 'economic turnaround or urban revitalisation' by the end of the decade. The survey was sent to members of the editorial boards of the leading American academic journals concerned with urban affairs and economic development (Urban Affairs Quarterly, Journal of Urban Affairs and Economic Development Quarterly), and to members of the Executive Boards of two leading economic development practitioner organisations, the American Economic Development Council (AEDC) and the Council on Urban Economic Development (CUED). Our response rate was 47.8 per cent ( 76 responses from 159 sampled).

We deemed 'successfully revitalised' those cities $(n=12)$ that were named by 20 per cent or more of the respondents, and 'most successfully revitalised' those cities $(n=6)$ that were named by 40 per cent or more of the respondents (Table 1). In order to ensure that the successfully revitalised cities did not differ from the other distressed cities as of 1980 (i.e. they were both part of the same distressed population), we compared the means of the two groups of cities using a difference of means test, and found no statistically significant difference between them.

Again, we emphasise that this process yielded only perceptions, albeit of reasonably informed people, and that this is what it was designed to do. We did not use it as a means of determining which cities had, in fact, successfully undergone urban revitalisation in objective terms, and we do not argue that perceptions accord with reality. We also do not know how these perceptions were formed. Our intent was to capture perceptions, based on what our informed respondents carried around in their minds, rather than to capture objective reality based on data.

Comparisons of the performance of the different groups of cities between 1980 and 1990 were then made on a series of indicators of the economic well-being of residents. We focus on the economic well-being of residents because the ultimate benefit of spatial revitalisation must be measured in terms of whether or not people (rather than tracts of land) are better off, and economic benefits are nearly universally recognised as being of substantial importance. 
EVALUATING THE SUCCESS OF URBAN SUCCESS STORIES

Table 1. The 'successfully revitalised' cities, $1980-90$

\begin{tabular}{|c|c|c|c|}
\hline Central city & State & Count & Response (\%) \\
\hline Pittsburgh & Pennsylvania & 63 & 82.9 \\
\hline Baltimore & Maryland & 49 & 64.5 \\
\hline Atlanta & Georgia & 40 & 52.6 \\
\hline Cleveland & Ohio & 37 & 48.7 \\
\hline Cincinnati & Ohio & 33 & 43.4 \\
\hline Louisville & Kentucky & 31 & 40.8 \\
\hline Miami & Florida & 23 & 30.3 \\
\hline Boston & Massachusetts & 22 & 28.9 \\
\hline Chicago & Illinois & 22 & 28.9 \\
\hline Birmingham & Alabama & 18 & 23.7 \\
\hline Buffalo & New York & 18 & 23.7 \\
\hline Norfolk & Virginia & 16 & 21.1 \\
\hline \multicolumn{3}{|c|}{ Total count } & 541 \\
\hline \multicolumn{3}{|c|}{ Total respondents } & 76 \\
\hline \multicolumn{3}{|c|}{ Average responses } & 7.12 \\
\hline \multicolumn{3}{|c|}{ Survey organizations $\quad R$} & ponses (Number) \\
\hline \multicolumn{3}{|c|}{ American Economic Development Council } & 13 \\
\hline \multicolumn{3}{|c|}{ Council on Urban Economic Development } & 18 \\
\hline \multicolumn{3}{|c|}{ Journal of Urban Affairs } & 11 \\
\hline \multicolumn{3}{|c|}{ Economic Development Quarterly } & 22 \\
\hline \multicolumn{3}{|c|}{ Urban Affairs Quarterly } & 14 \\
\hline \multicolumn{3}{|c|}{ Duplicate Membership (respondents) } & 2 \\
\hline \multicolumn{3}{|c|}{ Total respondents } & 76 \\
\hline \multirow{2}{*}{\multicolumn{2}{|c|}{$\begin{array}{l}\text { Total number surveyed } \\
\text { Survey response rate }(\%)\end{array}$}} & & 159 \\
\hline & & & 47.8 \\
\hline
\end{tabular}

Note: The 'successfully revitalised' cities were selected by respondents from a set of 50 cities that were experiencing distress in 1980 according to their scores on an index of urban health. (See Appendix note for a description of the methodology.)

How should economic well-being be conceptualised and operationalised? Conceptually, we define economic well-being of area residents to consist of the ability to purchase goods and services (income), the distribution of income among residents, and the ability to participate effectively in area labour markets (as a component of economic well-being itself, irrespective of the income such participation might produce). Since our concern is with change in economic well-being, operationally we seek measures of change in real income, in the distribution of income, and in the labour force status of area residents.

Three measures of change in income and the distribution of income were used: (1) percentage change in median household income and (2) percentage change in per capita income as measures of change in income, and (3) percentage point change in the rate of persons below the poverty line as a measure of distribution. We expect that 'successfully revitalised' cities will have experienced larger increases in both median household and per capita income and greater reductions in the rate of poverty than will the unrevitalised or 'unsuccessful' cities.

To operationalise the labour force status of area residents, we used two measures that are common in the labour economics literature: the percentage point change in the unemployment rate and the percentage point 
Table 2. Comparative performance of perceived 'successfully revitalised' and perceived 'unsuccessful' cities, $1980-90$

\begin{tabular}{lccr}
\hline Indicator & $\begin{array}{c}\text { Successful } \\
(N=12) \\
\text { Mean }\end{array}$ & $\begin{array}{c}\text { Unsuccessful } \\
(N=38) \\
\text { Mean }\end{array}$ & $\begin{array}{c}\text { Test statistic } \\
\text { (critical: } \\
-1.96,1.96)\end{array}$ \\
\hline Unemployment rate (percentage point change) & 1.40 & 1.27 & -0.347 \\
Poverty rate (percentage point change) & 2.53 & 2.91 & 0.275 \\
Labour force participation (percentage point change) & 2.78 & 2.70 & -0.111 \\
Median household income (percentage change) & 73.38 & 76.78 & 0.390 \\
Per capita income (percentage change) & 89.36 & 87.57 & -0.220 \\
Index of economic well-being ( $n$ scores) & -0.038 & 0.012 & 0.043 \\
\hline
\end{tabular}

Note: The index of well-being is the product of the summation of the standard scores for changes in five indicators of resident economic well-being between 1980 and 1990. These include: percentage point change in the unemployment rate, the rate of persons below the poverty line and the labour force participation rate; as well as percentage change in median household income and per capita income. The percentage point changes in the unemployment rate and the rate of persons below the poverty line are adjusted (multiplied by negative one) so that a positive sign on all indicators connotes relative improvement in economic well-being.

change in the labour force participation rate. Employment-the possession of a job-is seen as, in itself, an important component of economic well-being. Lower unemployment rates thus imply greater economic well-being for area residents. We expect that 'successfully revitalised' cities will have experienced a greater tightening of labour markets over the decade relative to 'unsuccessful' cities and, consequently, reductions in unemployment rates relative to these cities. This expectation is consistent with Bartik's (1991) work on state and local economic development policy.

Increases in labour force participation reflect increased optimism on the part of area residents about the prospects of gaining employment and thus, in our terms, an increase in their economic well-being. Eberts and Stone (1992) have conclusively shown that local labour markets adjust to fluctuations in the demand for labour by changing their labour force participation rates. Thus, we expect that if cities have truly revitalised, then their labour force participation rates will be higher than rates found in the unsuccessful cities.

We first compared the 12 'successfully revitalised' cities with the 38 other cities that were distressed in 1980 , but were perceived by our panel as not having undergone successful revitalisation over the decade. Next, we compared the 6 'most successfully revitalised' cities to the 38 'unsuccessful' cities.

\section{Findings}

Did the distressed cities which were perceived by our experts to have successfully revitalised during the past decade actually perform better than the other distressed cities in terms of our indicators of resident economic well-being? To answer this query, we compared the means of the supposedly 'successfully revitalised' cities with the means of the supposedly 'unsuccessful' cities on each of the five indicators. Since we were dealing with two populations of cities rather than samples (all cities in metropolitan areas of 250000 or more that were distressed in 1980), differences found between the populations were real differences, not sampling error. Nevertheless, in order to determine whether the observed differences were large enough to be significant under more rigorous statistical assumptions (i.e. if we considered the cities as a sample of all possible distressed cities over a long period of time), we 
Table 3. Comparative performance of perceived 'most successfully revitalised' and perceived 'unsuccessful' cities, $1980-90$

\begin{tabular}{lccr}
\hline Indicator & $\begin{array}{c}\text { Most } \\
\text { successful } \\
(N=6) \\
\text { Mean }\end{array}$ & $\begin{array}{c}\text { Unsuccessful } \\
(N=38) \\
\text { Mean }\end{array}$ & $\begin{array}{c}\text { Test statistic } \\
\text { (critical: } \\
-1.96,1.96)\end{array}$ \\
\hline Unemployment rate (percentage point change) & 1.30 & 1.27 & -0.058 \\
Poverty rate (percentage point change) & 3.03 & 2.91 & -0.055 \\
Labour force participation (percentage point change) & 2.47 & 2.70 & 0.296 \\
Median household income (percentage change) & 69.10 & 76.78 & 0.800 \\
Per capita income (percentage change) & 91.35 & 87.57 & -0.350 \\
Index of economic well-being (n scores) & -0.222 & 0.012 & 0.228 \\
\multicolumn{1}{c}{ Test criterion: $p=0.05, Z$ probability distribution } & & & \\
\hline
\end{tabular}

applied a difference of means test. In doing so, we found no statistically significant difference for any of the indicators (see Table 2).

Indeed, the 'successfully revitalised' cities were actually outperformed by the 'unsuccessful' cities on some of our indicators. The 'unsuccessful' cities did better than the 'successful' cities in terms of the percentage point change in the unemployment rate-the rate increased in the 'successful' cities by 1.40 percentage points, while it increased by 1.27 percentage points in the 'unsuccessful' cities. The 'unsuccessful' cities also saw greater improvements in median income than did the 'successful' cities ( 76.8 per cent in nominal dollars compared to 73.4 per cent). The 'successfully revitalised' cities did do slightly better than the 'unsuccessful' cities with respect to percentage change in per capita income and percentage point change in the poverty rate, but these differences were slight and as noted, far short of statistical significance.

We next constructed an overall index of economic well-being' as a summary measure of the change in resident economic well-being from 1980 to 1990 . The index was constructed by summing the standard scores of the five indicators (percentage point change in: the unemployment rate, labour force participation rate and the poverty rate and percentage change in median household income and in per capita income). The 'unsuccessful' cities actually had a slightly higher summary index of resident economic well-being than the 'successfully revitalised' cities $(0.012$ compared to -0.038 ), although the differences were not statistically significant.

In order to provide a more stringent test, we next compared the performance of the six 'most successfully revitalised' citiesthose which 40 per cent or more of the respondents had mentioned-with that of the 38 'unsuccessful' cities. Remarkably, the 'unsuccessful' cities outperformed the 'most successfully revitalised' cities on all of the five indicators of resident economic well-being (except change in per capita income) and on the summary index (0.012 compared to -0.222 ). Again, there were no statistically significant differences between the two groups of cities, either with respect to the individual indicators or the summary index of performance (see Table 3).

Since averages may hide important differences in individual city performance, we examined the individual means of the 6 'most successfully revitalised' cities on each indicator of economic well-being by comparing them to the means of the 38 'unsuccessful' cities. It is clear from this analysis (see Table 4) that two of the perceived 'most successfully revitalised' cities-Atlanta and Baltimore-did perform considerably better than the 'unsuccessful' cities. Baltimore per- 
Table 4. Individual city changes on the indicators of resident economic well-being, 'most successfully revitalised' cities, $1980-90$

\begin{tabular}{lccccc}
\hline & $\begin{array}{c}\text { Percentage } \\
\text { change in } \\
\text { median } \\
\text { house } \\
\text { Point change } \\
\text { unemployment }\end{array}$ & $\begin{array}{c}\text { Percentage } \\
\text { point change } \\
\text { in persons } \\
\text { incolow the } \\
\text { poverty line }\end{array}$ & $\begin{array}{c}\text { Percentage } \\
\text { change in } \\
\text { per capita } \\
\text { income }\end{array}$ & $\begin{array}{c}\text { Percentage } \\
\text { in the labour } \\
\text { force } \\
\text { participation } \\
\text { rate }\end{array}$ \\
\hline Pittsburgh & 2.2 & 54.7 & 4.9 & 83.8 & 1.5 \\
Baltimore & $0.1^{*}$ & 87.7 & $-1.0^{*}$ & $104.1^{*}$ & 3.7 \\
Atlanta & 1.5 & $97.2^{*}$ & $-0.2^{*}$ & $133.7^{*}$ & $4.1^{*}$ \\
Cleveland & 3.9 & 45.2 & 6.6 & 60.5 & 0.3 \\
Cincinnati & $-0.4^{*}$ & 65.7 & 4.6 & 82.5 & 3.2 \\
Louisville & $0.5^{*}$ & 64.1 & 3.3 & 83.5 & 2.0 \\
Mean 'unsuccessful cities' & 1.27 & 76.78 & 2.91 & 87.57 & 2.70 \\
\hline
\end{tabular}

Note: The values for each city that are half standard deviation units beyond the mean of the 'unsuccessful cities' $(n=38)$ for each indicator of resident economic well-being are marked with an asterisk.

formed better than the 'unsuccessful' cities on each of the five indicators; and on three of these indicators (unemployment rate, poverty rate and per capita income), Baltimore's mean was at least half a standard deviation better than the mean of the 'unsuccessful' cities. Atlanta performed better than the 'unsuccessful' cities on four of the five indicators (all but change in unemployment rate); and for each of these four indicators, Atlanta's mean was at least half a standard deviation better than the mean of the 'unsuccessful' cities. However, Cleveland and Pittsburgh performed more poorly than the 'unsuccessful' cities on all five of the indicators (indeed, Cleveland was more than half a standard deviation below the mean performance of the 'unsuccessful' cities on four of the five indicators), while Louisville performed more poorly on four of the indicators and Cincinnati on three.

We also examined separately the other six cities comprising the set of 'successfully revitalised' cities. Of the six, only Boston clearly outperformed the 'unsuccessful' cities, experiencing beneficial changes in the economic well-being of their residents as demonstrated by being half a standard deviation or more beyond the mean of the "unsuccessful' cities on four of the five indicators. Norfolk also outperformed the 'unsuccessful' cities on four of the five indicators, but on only one was it more than half a standard deviation better than their mean. The other four cities perceived to be 'successfully revitalised' (Miami, Chicago, Birmingham and Buffalo) all performed more poorly than the 'unsuccessful' cities on at least three of the five indicators of economic well-being (see Table 5).

It is possible that our survey respondents may have been focusing on metropolitan areas rather than central cities when they listed urban areas that experienced 'the strongest economic turnaround or urban revitalisation'. It is also possible that the impact of urban revitalisation may have exerted its most substantial economic effect on the residents of the entire metropolitan area rather than specifically on the residents of central cities, with suburban residents benefiting most from the increased economic viability of the central city. Accordingly, we repeated our analysis for the metropolitan areas of the 'successfully revitalised', 'most successfully revitalised', and 'unsuccessful' cities.

Unfortunately, it was not possible to gather labour force participation rate data on a comparable metropolitan area basis for both 1980 and 1990, so the metropolitan area 
Table 5. Individual city changes on the indicators of resident economic well-being, 'next most successfully revitalised' cities, $1980-90$

\begin{tabular}{lccccc}
\hline & $\begin{array}{c}\text { Percentage } \\
\text { change in } \\
\text { median } \\
\text { house } \\
\text { City }\end{array}$ & $\begin{array}{c}\text { Percentage } \\
\text { point change } \\
\text { in persons } \\
\text { below the } \\
\text { unemployment }\end{array}$ & $\begin{array}{c}\text { Percentage } \\
\text { income }\end{array}$ & $\begin{array}{c}\text { Percentage } \\
\text { per capita } \\
\text { point change } \\
\text { in the labour } \\
\text { income }\end{array}$ & $\begin{array}{c}\text { force } \\
\text { participation } \\
\text { rate }\end{array}$ \\
\hline Miami & 4.1 & 52.8 & 6.7 & 61.1 & 0.0 \\
Boston & 2.3 & $132.9 *$ & $-1.5^{*}$ & $137.7^{*}$ & $6.4^{*}$ \\
Chicago & 2.3 & 71.9 & 1.3 & 84.5 & 3.0 \\
Birmingham & $-1.7 *$ & 60.6 & 2.8 & 74.2 & 1.8 \\
Buffalo & $-0.6^{*}$ & 59.4 & 4.9 & 76.2 & 3.9 \\
Norfolk & 2.6 & 88.4 & $-1.4^{*}$ & 90.5 & 3.4 \\
Mean 'unsuccessful cities' & 1.27 & 76.78 & 2.91 & 87.57 & 2.70 \\
\hline
\end{tabular}

Note: The values for each city that are half standard deviation units beyond the mean of the 'unsuccessful cities' $(n=38)$ for each indicator of resident economic well-being are marked with an asterisk.

index of economic well-being consisted of four indicators rather than five. Nevertheless, our findings were essentially the same as for the previous analysis (see Table 6).

There were no statistically significant differences between the performance of the metropolitan areas of the 'successfully revitalised' cities and the metropolitan areas of the 'unsuccessful' cities. Indeed, the 'unsuccessful' metropolitan areas outperformed the 'successfully revitalised' metropolitan areas on three of the four indicators, having somewhat greater percentage increases in both median household and per capita income and a greater decline in the unemployment rate ( -1.69 percentage points compared to -1.03). The 'unsuccessful' areas also performed better on the summary index of resident economic well-being. We repeated the analysis for the six metropolitan areas of the 'most successfully revitalised' cities with much the same results (see Table 7).

Our analysis has convincingly shown that the so-called urban success stories were, on the whole, mythical-at least so far as the economic condition of the residents is concerned. We can now consider the question of which distressed cities did experience the best performance with respect to our summary index of resident economic well-being from 1980 to 1990 . The $n$ scores on the summary indicator for all the 50 cities are listed in order of performance (best to worst) in Table 8. The index consists of the summation of the city $n$ scores from each of the five indicators (percentage point change in unemployment rate, poverty rate and labour force participation rate; and percentage change in median household and per capita income). By these criteria, the six best-performing cities over the period are, in order, Wilmington, Paterson, Atlantic City, Jersey City, Boston and New York. Clearly there is a regional factor at work-for cities and their metropolitan areas are likely to perform in much the same manner as the region of which they are a part, and the Mid-Atlantic and New England regions performed very well during the 1980 s. Of the perceived 'most successfully revitalised' cities, Atlanta ranks 12th, Baltimore 14th, Cincinnati $21 \mathrm{st}$, Louisville 30th, Pittsburgh 38th and Cleveland 44th.

\section{Discussion}

We have examined the cities that are perceived to be 'urban success stories' and found that, taken as a group, they performed no better with respect to change in the economic well-being of their residents-and in many cases performed worse-than did other 
Table 6. Comparative performance of the metropolitan areas of perceived 'successfully revitalised' cities to the metropolitan areas of perceived 'unsuccessful' cities, 1980-90

\begin{tabular}{lccc}
\hline & $\begin{array}{c}\text { Most Successful } \\
(N=12) \\
\text { Mean }\end{array}$ & $\begin{array}{c}\text { Unsuccessful } \\
(N=38) \\
\text { Mean }\end{array}$ & $\begin{array}{c}\text { Test statistic } \\
\text { (critical: } \\
\text { Indicator }\end{array}$ \\
\hline Unemployment rate (percentage point change) & -1.03 & -1.69 & -1.36 \\
Poverty rate (percentage point change) & 0.37 & 0.51 & 0.21 \\
Median house income (percentage change) & 76.93 & 81.81 & 0.73 \\
Per capita income (percentage change) & 98.84 & 104.21 & 0.87 \\
Index of economic well-being ( $n$ scores) & -0.54 & 0.17 & 0.72 \\
\hline
\end{tabular}

cities that were equally distressed in 1980. We did find that three of the cities reputed to be successful-Atlanta, Baltimore and Boston-performed considerably better than the other distressed cities; they could justifiably be termed 'urban success stories', although, with the possible exception of Boston, they were by no means the best performers of the distressed cities.

How can we account for these findings, and how do we interpret them? First, we must state the obvious: we purposefully did not define the terms 'economic turnaround' or 'urban revitalisation' for our respondents, and it is uncertain what criteria they were using when they identified those cities that had experienced the 'strongest economic turnaround or urban revitalisation'. It is clear, however, that improvement in the economic well-being of the residents was not the criterion by which urban revitalisation was being measured, or, if it was, it was badly misperceived.

If we were to define urban revitalisation in objective terms (e.g. an increase in residential, commercial and industrial investment in the city), it may be that some or all of these cities did not undergo urban revitalisation at all. Or, perhaps, these cities did experience such revitalisation, but it did not produce an improvement in the relative economic wellbeing of their residents. Instead, 'urban revitalisation' might have been manifested in improvements in the city's economic base (e.g. an increase in the number of jobs located in the city) or fiscal condition. Indeed, it is possible that one or both of these conditions may have served as implicit criteria by which our respondents identified cities which had undergone economic turnaround or urban revitalisation.

In the end, of course, we do not know what was in the minds of our respondents or why they responded as they did. This is an interesting subject, and one worthy of further research. An initial hypothesis is that perception of downtown redevelopment efforts greatly influences perception of urban success. (Physical development is frequently viewed by planners and development professionals as the leading indicator, if not the culmination, of revitalisation. See Frieden and Sagalyn, 1989). If this hypothesis is valid, then the cities that are perceived as most revitalised will be those that experienced the most substantial improvement in their central business districts, the most visible part of an area's image. Redevelopment of the central business district in terms of both new office buildings and the presence of retail stores and boutiques, recreational opportunities and tourist attractions may drive public perceptions of the well-being of the entire urban area. However, if this hypothesis is true, then it must be said that improved downtown image did not translate, at least immediately, into improvements in the economic well-being of residents, either in the city or in the metropolitan area as a whole. ${ }^{4}$

An interesting, though highly speculative explanation, can also be constructed from the data we have presented on the performance 
Table 7. Comparative performance of the metropolitan areas of perceived 'most successfully revitalised' cities to the metropolitan areas of perceived 'unsuccessful' cities, 1980-90

\begin{tabular}{lccr}
\hline Indicator & $\begin{array}{c}\text { Most Successful } \\
(N=12) \\
\text { Mean }\end{array}$ & $\begin{array}{c}\text { Unsuccessful } \\
(N=38) \\
\text { Mean }\end{array}$ & $\begin{array}{c}\text { Test statistic } \\
\text { (critical: } \\
-1.96,1.96)\end{array}$ \\
\hline Unemployment rate (percentage point change) & -1.28 & -1.69 & -0.83 \\
Poverty rate (percentage point change) & 0.48 & 0.51 & 0.03 \\
Median house income (percentage change) & 73.00 & 81.81 & 1.02 \\
Per capita income (percentage change) & 99.13 & 104.21 & 0.71 \\
Index of economic well-being (n scores) & -0.63 & 0.17 & 0.70 \\
\multicolumn{1}{l}{ Test criterion: $p=0.05, Z$ probability distribution } & & & \\
\hline
\end{tabular}

of the 'most successfully revitalised' cities relative to the 'unsuccessful' ones. First of all, per capita income increased more in the six 'most successfully revitalised' cities than in the unsuccessful ones, but median household income increased more in the 38 'unsuccessful cities'. The only possible explanation for this is that household size declined more rapidly in the most successful cities, which would be consistent with a relatively greater increase in young single individuals and childless couples (yuppies) frequently associated with revitalisation of downtown areas and gentrification. The small, but greater increase, in the unemployment rate and poverty rate in the 'most successfully revitalised' cities would be consistent with a worsening of the income distribution and growing disparities between the wealthy and the poor.

\section{Summary and Conclusion}

We begin by emphasising what we did find and what we did not. Cities that have been perceived as 'urban success stories' have not, in fact, been successful, at least in so far as improving the economic well-being of their residents. The change in the economic wellbeing of residents of cities that are typified as 'urban success stories' between 1980 and 1990 did not differ from-and in some cases was inferior to-change in the economic well-being of residents of other cities that were (like the 'urban success stories') distressed in 1980.

Our findings do not suggest that actual (as opposed to perceived) urban revitalisation might not lead to improvements in the economic well-being of residents, unless one assumes (and we do not) that the correspondence between perceived and actual urban revitalisation is exact. Our findings relate to the common perceptions which drive policymakers (and urban experts as well) to evaluate city performance and learn from 'successes'. We argue that efforts to copy the policies and development activities of these 'success stories' may well be misplaced, at least if improving the economic well-being of area residents is the goal that is being pursued.

We have no data that relate to actual urban revitalisation. It would indeed be useful to identify which cities have actually achieved urban revitalisation and to examine the effect of revitalisation on economic well-being. Such an effort would require a careful conceptual definition of urban revitalisation and selection of a corresponding operational variable for which data could be collected.

Our work also raises interesting questions about what urban experts, policy-makers and others mean when they make use of the term 'urban revitalisation'. We view this as an important question, since we believe that mental constructs about the nature of a phenomenon are important determinants of 
Table 8. Central city economic performance on the index of economic well-being, 1980-90 (emboldened cities are those selected as 'successfully revitalised'.)

\begin{tabular}{|c|c|c|}
\hline Central city & State & Index score \\
\hline Wilmington & Delaware & 9.388 \\
\hline Paterson & New Jersey & 7.374 \\
\hline Atlantic City & New Jersey & 6.120 \\
\hline Jersey City & New Jersey & 5.960 \\
\hline Boston & Massachusetts & 5.943 \\
\hline New York & New York & 4.487 \\
\hline New Haven & Connecticut & 4.422 \\
\hline Newark & New Jersey & 4.027 \\
\hline New Brunswick & New Jersey & 3.767 \\
\hline Trenton & New Jersey & 3.650 \\
\hline Bridgeport & Connecticut & 3.515 \\
\hline Atlanta & Georgia & 3.482 \\
\hline Albany & New York & 3.470 \\
\hline Baltimore & Maryland & 2.835 \\
\hline Philadelphia & Pennsylvania & 1.632 \\
\hline Reading & Pennsylvania & 1.516 \\
\hline Scranton & Pennsylvania & 1.090 \\
\hline Providence & Rhode Island & 0.774 \\
\hline Norfolk & Virginia & 0.703 \\
\hline York & Pennsylvania & 0.552 \\
\hline Cincinnati & Ohio & 0.007 \\
\hline Utica & New York & -0.064 \\
\hline Birmingham & Alabama & -0.069 \\
\hline Springfield & Massachusetts & -0.140 \\
\hline Chicago & Illinois & -0.142 \\
\hline Syracuse & New York & -0.166 \\
\hline Buffalo & New York & -0.228 \\
\hline Binghamton & New York & -0.297 \\
\hline New Bedford & Massachusetts & -0.316 \\
\hline Louisville & Kentucky & -0.334 \\
\hline Augusta & Georgia & -0.497 \\
\hline Macon & Georgia & -0.661 \\
\hline St. Louis & Missouri & -0.919 \\
\hline Hartford & Massachusetts & -0.936 \\
\hline Akron & Ohio & -1.194 \\
\hline Harrisburg & Pennsylvania & -1.250 \\
\hline Rochester & New York & -1.335 \\
\hline Pittsburgh & Pennsylvania & -2.066 \\
\hline Dayton & Ohio & -2.184 \\
\hline Huntington & West Virginia & -3.863 \\
\hline Canton & Ohio & -4.236 \\
\hline New Orleans & Louisiana & -4.597 \\
\hline Saginaw & Michigan & -5.253 \\
\hline Cleveland & Ohio & -5.334 \\
\hline Miami & Florida & -5.758 \\
\hline Flint & Michigan & -5.967 \\
\hline Detroit & Michigan & -5.967 \\
\hline Johnstown & Pennsylvania & -6.886 \\
\hline Gary & Indiana & -7.001 \\
\hline Youngstown & Ohio & -8.080 \\
\hline
\end{tabular}

Note: See text for an explanation of the creation and composition of this index. 
how policy-makers frame both problems and solutions. 'Urban revitalisation', whatever it is, has a highly positive valence; it is seen to be a good thing, worthy of pursuit and emulation. But of what does this good thing consist? Clearer understanding of what people mean by 'urban revitalisation' might also lead to more critical thinking about which aspects of it are indeed 'good' and which are more problematic. This, too, is worthy of additional research.

In future work, we intend to examine what factors account for the performance of those distressed cities that actually improved the economic well-being of their residents. Two important questions that arise are what factors accounted for their superior performance and to what extent can that performance be attributed to policy choices made by these cities, rather than to regional and national economic factors? Using the same data set we also intend to examine the relative performance of central cities and their metropolitan areas and address the extent to which central city economic performance affects the performance of the city's suburbs and the metropolitan area as a whole.

\section{Notes}

1. The popular press has written extensively on the subject of 'comeback cities' or 'urban success stories', focusing largely on the physical revitalisation of the downtown cores. See, for example, "Spiffing up the Urban Heritage" Time, 23 November 1987; "When Cities Smile Again" The Economist, 16 January 1988; "The Rest of the Major Cities" Fortune, 23 October 1989 and "You Wanna Meet Here", Sales and Marketing Management, November 1990.

2. $\quad N$ scores are conceptually equivalent to $z$ scores, but are distributed in standard deviation units from the median rather that the mean. Thus, $n$ scores have the advantage of being less influenced by sample outliers in the creation of a distribution of scores.

3. The signs on the standard scores of the unemployment rate and poverty rate were reversed (multiplied by negative one) in the index, so that a positive score constituted an improvement in economic condition.

4. Indeed, it would suggest that the downtown development and increased activity, if it oc- curred, involved redistribution of economic activity from other parts of the metropolitan area to downtown rather than an increase in overall economic activity. However, even if this hypothesis is true, we hasten to add that we are not arguing that downtown development and enhancement of a city's image may not have some beneficial effects in terms of the residents' own image of their city and consequent psychological improvements in their quality of life, or indeed, in terms of economic development and economic wellbeing. It may be true (it may not as well) that any positive economic development gains derived from a city's image enhancement require a substantial lead time before investors of mobile capital respond. Baltimore, Boston and Atlanta have, it is true, been recognised as 'urban success stories' longer that have Pittsburgh and Cleveland.

\section{References}

BARnekov, T., Boyle, R. and Rich, D. (1989) Privatism and Urban Policy in Britain and the United States. Oxford: Oxford University Press.

BARTIK, T. (1991) Who Benefits from State and Local Economic Development Policies? Kalamazoo, MI: W. E. Upjohn Institute.

BERKOWITZ, B. (1987) Rejoinder to downtown redevelopment: a critical appraisal of the Baltimore renaissance, Journal of Urban Affairs, 9(2), pp. 125-132.

BRADBURY, K., Downs, A. and SMALl, K. (1982) Urban Decline and the Future of American Cities. Washington, DC: Brookings Institution.

BRownHILL, S. (1990) Developing London Docklands. London: Paul Clapham.

Clavel, P. (1986) The Progressive City. New Brunswick, NJ: Rutgers University Press.

CucITI, P. (1978) City Need and the Responsiveness of Federal Grants. Washington, DC: Congressional Budget Office.

EBERTS, R. and STONE, J. (1992) Wage and Employment Adjustment in Local Labor Markets. Kalamazoo, MI: W. E. Upjohn Institute.

Fainstein, S., Fainstein, F., Hill, R.C., JudD, D. and SMITH, M.P. (1986) Restructuring the City: The Political Economy of Urban Development. New York: Langman.

FosseTt, J. and NATHAN, R. (1981) The prospects for urban renewal, in: R. BAHL (Ed.) Urban Government Finance. Beverly Hills, CA: Sage.

Frieden, B. and Sagalyn, L. (1989) Downtown Inc: How America Rebuilds Cities. Cambridge, MA: MIT Press.

JAMES, F. (1990) City needs and distress in the United States: 1970s to the mid 1980s, in: M. KAPLAN and F. JAMES (Ed.) The Future of 
National Urban Policy. Durham, NC: Duke University Press.

LADD, H. and YINGER, J. (1989) America's Ailing Cities. Baltimore: Johns Hopkins University Press.

Levine, M. (1987a) Downtown redevelopment as an urban growth strategy, Journal of Urban Affairs, 9(2), pp. 103-123.

LEVINE, M. (1987b) Response to Berkowitz, economic development in Baltimore: some additional perspectives, Journal of Urban Affairs, 9, pp. 133-138.

NATHAN, R. and ADAMS, C. (1976) Understanding central city hardship, Political Science Quarterly, 91 , pp. $47-62$.
RIPOSA, G. and ANDRANOvich, G. (1988) Whose interests are being served in economic development policy, Urban Resources, 5, pp. 25-34.

STERNLIEB, G. (1980) Measuring Urban Distress: A Summary of the Major Urban Hardship Indicators and Resource Allocation. New Brunswick, NJ: Rutgers University Press.

SQUIRES, G. (Ed.) (1989) Unequal Partnerships: The Political Economy of Urban Redevelopment in Post-war America. New Brunswick, NJ: Rutgers University Press.

Wolman, H. and Goldsmith, M. (1992) Urban Politics and Policy: A Comparative Approach. Oxford: Basil Blackwell.

Appendix. Central City Performance on the Index of Urban Health, 1980

\begin{tabular}{|c|c|c|}
\hline Central city & State & Index score \\
\hline Lexington-Fayette & Kentucky & 8.236 \\
\hline San Jose & California & 7.948 \\
\hline Anaheim & California & 7.191 \\
\hline Houston & Texas & 6.678 \\
\hline Bakersfield & California & 6.326 \\
\hline Appleton & Wisconsin & 6.299 \\
\hline Tulsa & Oklahoma & 5.894 \\
\hline Wichita & Kansas & 5.719 \\
\hline Honolulu & Hawaii & 5.713 \\
\hline Raleigh & North Carolina & 5.705 \\
\hline Santa Rosa & California & 5.664 \\
\hline Davenport & Iowa & 5.525 \\
\hline Aurora & Illinois & 4.893 \\
\hline Austin & Texas & 4.890 \\
\hline Colorado Springs & Colorado & 4.877 \\
\hline Oklahoma City & Oklahoma & 4.676 \\
\hline Phoenix & Arizona & 4.675 \\
\hline Portsmouth & New Hampshire & 4.625 \\
\hline Charlotte & North Carolina & 4.622 \\
\hline Santa Barbara & California & 4.078 \\
\hline Nashville-Davidson & Tennessee & 3.957 \\
\hline Modesto & California & 3.890 \\
\hline Waukegan & Illinois & 3.822 \\
\hline Little Rock & Arkansas & 3.717 \\
\hline Corpus-Christi & Texas & 3.610 \\
\hline Dallas & Texas & 3.483 \\
\hline Albuquerque & New Mexico & 3.416 \\
\hline Las Vegas & Nevada & 3.281 \\
\hline Oxnard & California & 3.226 \\
\hline Madison & Wisconsin & 3.198 \\
\hline Evansville & Indiana & 3.140 \\
\hline Charleston & West Virginia & 2.966 \\
\hline Riverside & California & 2.946 \\
\hline Des Moines & Iowa & 2.832 \\
\hline Omaha & Nebraska & 2.824 \\
\hline Manchester & New Hampshire & 2.815 \\
\hline Baton Rouge & Louisiana & 2.804 \\
\hline
\end{tabular}


EVALUATING THE SUCCESS OF URBAN SUCCESS STORIES

Appendix.-Continued.

\begin{tabular}{|c|c|c|}
\hline Central city & State & Index score \\
\hline Vallejo & California & 2.741 \\
\hline San Diego & California & 2.658 \\
\hline Shreveport & Louisiana & 2.639 \\
\hline Ann Arbor & Michigan & 2.545 \\
\hline Chattanooga & Tennessee & 2.529 \\
\hline Beaumont & Texas & 2.459 \\
\hline Greensboro & North Carolina & 2.340 \\
\hline Jacksonville & Florida & 2.306 \\
\hline Denver & Colorado & 2.219 \\
\hline Fort Lauderdale & Florida & 2.217 \\
\hline Joliet & Illinois & 2.019 \\
\hline Peoria & Illinois & 1.995 \\
\hline Fort Worth & Texas & 1.926 \\
\hline Orlando & Florida & 1.928 \\
\hline Melbourne & Florida & 1.901 \\
\hline Tucson & Arizona & 1.824 \\
\hline West Palm Beach & Florida & 1.698 \\
\hline Eugene & Oregon & 1.576 \\
\hline Duluth & Minnesota & 1.460 \\
\hline Johnson City & Tennessee & 1.455 \\
\hline Montgomery & Alabama & 1.399 \\
\hline Pensacola & Florida & 1.301 \\
\hline Salinas & California & 1.281 \\
\hline Indianapolis & Indiana & 1.171 \\
\hline Charleston & South Carolina & 1.125 \\
\hline Mobile & Alabama & 1.069 \\
\hline McAllen & Texas & 1.005 \\
\hline Portland & Oregon & 0.928 \\
\hline Fresno & California & 0.908 \\
\hline Lakeland & Florida & 0.899 \\
\hline Rockford & Illinois & 0.862 \\
\hline Columbus & Ohio & 0.847 \\
\hline Minneapolis & Minnesota & 0.753 \\
\hline San Francisco & California & 0.602 \\
\hline Fort Wayne & Indiana & 0.428 \\
\hline Allentown & Pennsylvania & 0.418 \\
\hline San Antonio & Texas & 0.306 \\
\hline Greenville & South Carolina & 0.255 \\
\hline Kansas City & Missouri & 0.238 \\
\hline Lorain & Ohio & 0.216 \\
\hline Milwaukee & Wisconsin & 0.196 \\
\hline Seattle & Washington & 0.187 \\
\hline Jackson & Mississippi & 0.161 \\
\hline Spokane & Washington & 0.155 \\
\hline Tampa & Florida & 0.147 \\
\hline Sacramento & California & 0.066 \\
\hline Los Angeles & California & 0.049 \\
\hline Memphis & Tennessee & 0.032 \\
\hline Lansing & Michigan & -0.019 \\
\hline Tacoma & Washington & -0.139 \\
\hline Salt Lake City & Utah & -0.212 \\
\hline Knoxville & Tennessee & -0.332 \\
\hline Hamilton & Ohio & -0.360 \\
\hline Stockton & California & -0.372 \\
\hline Washington & District of Columbia & -0.537 \\
\hline
\end{tabular}


EVALUATING THE SUCCESS OF URBAN SUCCESS STORIES

Appendix.-Continued.

\begin{tabular}{|c|c|c|}
\hline Central city & State & Index score \\
\hline El Paso & Texas & -0.596 \\
\hline Worchester & Massachusetts & -0.660 \\
\hline Erie & Pennsylvania & -0.680 \\
\hline Toledo & Ohio & -1.005 \\
\hline Columbia & South Carolina & -1.214 \\
\hline Grand Rapids & Michigan & -1.338 \\
\hline Oakland & California & -1.606 \\
\hline Lancaster & Pennsylvania & -1.705 \\
\hline Richmond & Virginia & -1.739 \\
\hline Daytona Beach & Florida & -1.746 \\
\hline Huntington & West Virginia & -1.884 \\
\hline Macon & Georgia & -1.947 \\
\hline Springfield & Massachusetts & -2.130 \\
\hline New Orleans & Louisiana & -2.189 \\
\hline Pittsburgh & Pennsylvania & -2.259 \\
\hline Norfolk & Virginia & -2.335 \\
\hline Boston & Massachusetts & -2.399 \\
\hline Scranton & Pennsylvania & -2.577 \\
\hline Akron & Ohio & -2.705 \\
\hline Chicago & Illinois & -2.746 \\
\hline Albany & New York & -2.840 \\
\hline Canton & Ohio & -2.847 \\
\hline Gary & Indiana & -2.862 \\
\hline York & Pennsylvania & -3.013 \\
\hline Binghamton & New York & -3.148 \\
\hline New Bedford & Massachusetts & -3.282 \\
\hline Cincinnati & Ohio & -3.346 \\
\hline Miami & Florida & -3.492 \\
\hline Rochester & New York & -3.508 \\
\hline Flint & Michigan & -3.510 \\
\hline Philadelphia & Pennsylvania & -3.560 \\
\hline Bridgeport & Connecticut & -3.645 \\
\hline Reading & Pennsylvania & -3.679 \\
\hline Syracuse & New York & -3.682 \\
\hline Birmingham & Alabama & -3.762 \\
\hline New Brunswick & New Jersey & -3.770 \\
\hline Johnstown & Pennsylvania & -3.848 \\
\hline Louisville & Kentucky & -3.986 \\
\hline New York & New York & -4.295 \\
\hline Harrisburg & Pennsylvania & -4.485 \\
\hline Baltimore & Maryland & -4.558 \\
\hline Trenton & New Jersey & -4.701 \\
\hline Utica & New York & -4.710 \\
\hline Providence & Rhode Island & -4.731 \\
\hline Youngstown & Ohio & -4.798 \\
\hline Jersey City & New Jersey & -5.226 \\
\hline Wilmington & Delaware & -5.446 \\
\hline New Haven & Connecticut & -5.453 \\
\hline Saginaw & Michigan & -5.552 \\
\hline Dayton & Ohio & -6.025 \\
\hline Atlanta & Georgia & -6.057 \\
\hline St. Louis & Missouri & -6.405 \\
\hline Cleveland & Ohio & -6.517 \\
\hline Hartford & Connecticut & -6.727 \\
\hline Buffalo & New York & -6.809 \\
\hline
\end{tabular}


EVALUATING THE SUCCESS OF URBAN SUCCESS STORIES

Appendix.-Continued.

\begin{tabular}{lll}
\hline Central city & State & Index score \\
\hline Atlantic City & New Jersey & -6.827 \\
Paterson & New Jersey & -7.058 \\
Detroit & Michigan & -7.085 \\
Augusta & Georgia & -7.841 \\
Newark & New Jersey & -9.154 \\
\hline
\end{tabular}

Notes: The index of urban health is the product of the summation of standardscores for a population of central cities $(n=152)$ on five indicators of economic well-being: percentage change in population 1970-80; percentage unemployed 1980; median household income 1980; percentage of persons below the poverty line 1980; and percentage change in per capita income 1970-80. The scores for percentage unemployed and percentage of persons below the poverty line are adjusted (multiplied by negative one) so that a positive score on all indicators connotes relative economic health.

The emboldened entry constitutes the breaking point between the bottom third of the cities and the remainder of the them. All cities that are at, or lie below, the breaking point were designated as 'distressed' and included in the survey mailing. 